Çukurova Üniversitesi Mühendislik Mimarlık Fakültesi Dergisi, 29(2), 27-38 ss., Aralık 2014

Çukurova University Journal of the Faculty of Engineering and Architecture, 29(2), pp. 27-38, December 2014

\title{
Meme Kanseri Tespitinde Mikrodalgaların Önemi ve Kanserli/Sağlıklı Meme Dokularının Yapay Zeka Algoritmaları ile Tanımlanabilmesi
}

\author{
Emine AVŞAR AYDIN ${ }^{* 1}$ \\ ${ }^{1}$ Çukurova Üniversitesi, Mühendislik-Mimarlık Fakültesi, Elektrik-Elektronik Mühendisliği, \\ Adana
}

Geliș tarihi: 15.07.2014 Kabul tarihi:24.10.2014

\section{Özet}

Dünyada akciğer kanserinden sonra en sık rastlanan kanser türü meme kanseri olmasına rağmen; erken tanı meme kanserini tehlikeli olmaktan çıkarmaktadır. Kanserli hücreleri tespit etmek amacıyla birçok yöntem geliştirilmiştir. Mikrodalga frekanslarında kötü huylu kanser hücrelerinin elektriksel özellikleri normal hücrelere göre belirgin farklılıklar göstermektedir. Bu frekanslarda gögüs dokusunun, beyin ve kas gibi diğer dokulara göre daha geçirgen olması, mikrodalga frekansında elektromanyetik dalgaların kanserli hücrelerin görüntülenmesinde kullanılması fikrini desteklemektedir. Meme kanseri teşhisinde kullanılan mamografi gibi birçok tekniğin kötü huylu hücrelerin tespitinde yetersiz kalması, maliyetlerinin yüksek olması ve hastanın zararlı ışınlara, rahatsız edici durumlara maruz kalması arzu edilen bir durum değildir. Bu makalenin amaçlarından biri; kanserin erken safhalarında tümörlerin çok daha küçük olduğunu ve mikrodalga görüntüleme yönteminin küçük tümörlerin tespitinde yüksek potansiyeli ile iyi bir aday olduğunu göstermektir. İkincisi ise; dokuların elektriksel özelliklerini kullanarak sınıflandırılabileceklerini göstermek açısından literatürde var olan, sağlıklı ve kanserli doku hücrelerinin elektriksel empedansı spektroskopi (EES) yöntemi ile elde edilen veri setinden yararlanılarak İleri Beslemeli Geriye Yayılımlı Yapay Sinir Ağı (İBGY-YSA) ve Destek Vektör Makineleri (DVM) gibi algoritmalar arasından en iyi sınıflama performansına sahip makine öğrenme yöntemi karşılaştırmalı olarak belirlemektir. Genel olarak sonuçlar incelendiğinde farklı elektriksel özellikleri bakımından kanserli ve normal meme dokularının bu yöntemlerle ayırt edilebildikleri görülmektedir ve Mikrodalga Görüntüleme bir takım umut verici stratejiler ortaya çıkarmıştır.

Anahtar Kelimeler: Mikrodalga görüntüleme, Elektriksel özellikler, Elektriksel empedansı spektroskopi (EES), İleri beslemeli geriye yayılımlı yapay sinir ağı (İBGY-YSA), Destek vektör makineleri (DVM)

\section{The Importance of Microwaves in the Detection of Breast Cancer and the Identification of Cancer/Healthy Breast Tissues by Artificial Intelligence Algorithms}

\begin{abstract}
Although the breast cancer is the second most common cancer after lung cancer in the world, early diagnosis plays an important role to decrease the death rate.

\footnotetext{
* Yazışmaların yapılacağı yazar: Emine Avşar AYDIN, Çukurova Üniversitesi Mühendislik-Mimarlık Fakültesi, Elektrik-Elektronik Mühendisliği, Adana, avsare@cu.edu.tr
} 
Many methods have been developed to detect the For these frequencies, the breast tissue is more permeable than other tissues such as brain, muscle. Due to this property of the breast tissue, the microwaves can be used for detecting of breast cancer. Other methods, such as mammography, are inadequate for detection of the small kind of malignant cells and harmful because of their X - Ray radiation. One of the purposes of this paper is to show that tumors are much smaller in early stages of cancer and microwave imaging is a good candidate with high potential for detection of small tumors. Secondly, in order to show that the tissues can be classified based on their dielectric properties; a currently available electrical impedance spectroscopy (EIS) data set is used. The data in the set is consists of EIS values of the healthy and cancerous tissues. Different machine learning algorithms such as Feed Forward Back Propagation Neural Network (FFBP-NN) and Support Vector Machines (SVM) are used and the results are compared to find the best classification method. As a result, the healthy and cancerous tissues can be identified by these methods and Microwave Imaging has revealed a number of promising strategies.

Keywords: Microwave imaging, Electrical properties, Electrical impedance spectroscopy (EIS), Feed forward back propagation neural network (FFBP-NN), Support vector machines (SVM)

\section{GíRIŞ}

Kanser, Türkiye'de ölüm nedenleri arasında kalp ve damar hastalıklarından sonra ikinci sirada bulunmaktadır ve kadınlarda görülme sıklı̆̆ı olarak meme kanseri, kanser türleri arasında ilk sırada yer almaktadır [1]. Meme kanserinin erken evrede tespiti, geç kalınması halinde kanserli hücrelerin metastaz yapabilmesinden dolay1, oldukça önemlidir. Meme kanserinin tespiti ve görüntülemesi için yaygın ve birincil olarak kullanılan yöntem, x-ray mamografidir. Ancak görüntüleme sırasında memenin sıkıştırılması ve düşük güçte de olsa iyonize edici radyasyonun kullanılması, X-ray mamografinin dezavantajıdır. $\mathrm{Bu}$ dezavantajlar, manyetik rezonans görüntüleme (MRG) ultrason görüntüleme (USG) gibi görüntüleme yöntemlerinin geliştirilmesinde önemli etkenler olmuşlardır. Ancak bu yöntemler de pahalılık ve kanserli dokular için düşük belirginlik gibi bazı dezavantajlara sahiptir. Mevcut yöntemlerin bu tür olumsuzluklar, araştırmacıları nispeten yeni bir yöntem olan mikrodalga tabanlı görüntüleme tekniğinin geliştirilmesine yöneltmiştir. Mikrodalga görüntüleme, iyonize etmeyen mikrodalga frekanslarında, kanserli dokular ile normal dokuların dielektrik özellikleri arasındaki yüksek kontrastın efektif bir şekilde kullanımı ile görüntülenmesine dayanmaktadır ve bilinen X-ray mamografinin bazı sakıncalarının üstesinden gelebilecek bir potansiyele sahip olduğu öngörülmektedir.

\subsection{Meme Kanseri}

Sebep olduğu ölümler göz önüne alındığında, tüm kadınlar için ciddi bir sorun haline gelen meme kanseri, göğüs dâhil, köprücük kemiği ve koltuk altı arasındaki geniş alanı kapsayan ve göğüs kasları üzerine uzanan meme dokusunda oluşmaktadır [2]. Her meme, süt kanalları, meme bezleri ve yağ dokusundan oluşmakta ve lob olarak adlandırılan 15 - 20 adet bağımsız süt üreten doku içermektedir. Her lob, kendi içinde lobül adı verilen 20 - 40 adet daha küçük alt dokuya; her lobül de yine kendi içinde alveol adı verilen ve esas süt üreten hücrelerin toplandığı çok sayıda bölüme ayrılır. Üretilen süt alveollerden duktül adı verilen kanalcıklara, oradan da duktus adı verilen büyük kanallara geçerek dışarı taşınmaktadır. Lobüller ve süt kanalları arası boşluklar yağ dokusu ile doludur.

Her kadının göğüs yapısı, doğaları gereği sahip oldukları regl döngüsünden dolayı farklıdır. Aynı zamanda, meme dokusunun yapısı, yaşa bağlı olarak farklılık göstermektedir. Örneğin, genç kadınların meme dokusunda meme bezleri ve süt kanalları var iken yaşlı kadınların meme dokusunda çoğunlukla yağ dokusu bulunmaktadır. 
Meme kanseri oluşumunun temel sebebi, hücrelerin büyümesini denetleyen genlerde meydana gelebilen mutasyonlar veya anormal değişikliklerdir [2]. Sağlıklı bir hücre ne zaman ve nerede bölünebileceğini bilme yeteneğine sahiptir. Buna karşın, bu bilinci kaybeden hücreler kontrolsüz bir şekilde bölünerek kanserli hücreleri oluşturmaktadır. Meme kanseri genellikle lobüllerde ya da süt kanallarında ortaya çıkmaktadır.

Kadınlarda akciğer kanserinden sonra en çok rastlanan kanser türü olan meme kanseri dünyada 8 kadından birinde ülkemizde 9-10 kadından birinde ortaya çıkmaktadır. Her zaman denildiği gibi erken teşhis edildiği takdirde meme kanseri prognozu ümit vericidir. Çizelge 1'de erken teşhisin ne kadar önemli olduğu açıkça görülmektedir. Bu durum da çok küçük kötü huylu dokuların tespiti için bile yeni yöntemler gerektiği açıktır [3].

Çizelge 1. Meme kanserinin aşamalarına göre bağıl kurtulma şansları [4].

\begin{tabular}{|c|c|}
\hline Safha & 5-Yıl Bağıl Kurtulma Şansı \\
\hline 0 & $\% 100$ \\
\hline I & $\% 100$ \\
\hline IIA & $\% 92$ \\
\hline I B & $\% 81$ \\
\hline IIIA & $\% 67$ \\
\hline III & $\% 54$ \\
\hline IV & $\% 27$ \\
\hline
\end{tabular}

\subsection{Meme Kanserinde Mikrodalgaların Önemi}

Mikrodalga görüntüleme tekniklerinden biri olan ve değişik alanlarda uygulamaları olan yüzey-altı tarama problemleri günümüzde oldukça ilgi çeken bir konu haline gelmiştir. Yüzey-altı görüntüleme; toprak altında, deniz altında, doku altında, hatta çevremizde yapay yapıların altında bulunan cisimlerin tespitinde kullanılan X-1şını, elektromanyetik, elektrik ve ultrasonik metotları içine alan bir disiplindir.

İyonlaştırmayan elektromanyetik dalgaların insan vücudundaki kanserli hücreleri tespit etme çalışmaları günümüzde biyomedikal uygulamalarda yaygın olarak kullanılmaktadır [5]. Hasta görüşlerine göre, mikrodalga ile meme görüntüleme oldukça iyi bir yöntemdir [6]. Çünkü hem iyonlaştırıcı radyasyonun zararlarından korur hem de meme sıkıştırılması gibi rahatsız edici durumları engeller. Sonuç olarak, güvenli ve rahattır.

Teknik olarak bakıldığında, mikrodalga ile meme kanseri tespiti çok küçük tümörleri belirlemesi açısından güçlü bir potansiyele sahiptir. Aynı zamanda Manyetik Rezonans Görüntüleme (MRG) ve nükleer tıp gibi yöntemlere göre daha $a z$ maliyetli olacağı öngörülmektedir. Ayrıca görüntüleme işleminin çok daha hızlı ve duyarlı olacağı açıktır. Çünkü Manyetik Rezonans Görüntülemenin temel metodu, Maxwell denklemlerinin ters çözümlerine dayandığından matematiksel işlemi oldukça uzun ve zahmetlidir [7].

Kesin önleyen bir yöntem olmamasının yanında erken tanı ile meme kanserinin getirdiği sorunlar büyük ölçüde çözülebilmektedir. Dünyada akciğer kanserinden sonra en s1k rastlanan kanser türü meme kanseri olmasına rağmen erken tanı meme kanserinde olumlu sonuçlar elde edilmesini sağlamaktadır [8].

Meme kanseri tespitiyle ilgili yapılmış birçok çalışma bulunmaktadır. Yapılan çalışmaların bir kısmı simülasyon ortamında gerçekleştirilmiş bir kısmında da modeller üretilmiştir. Yine bazı çalışmalarda gerçek dokular kullanılarak deneyler yapılmıştır.

Kanser ameliyatlarından elde edilen kanserli, iyi huylu ve normal dokuların ultra geniş-bant aralığında dielektrik özellikleriyle ilgili bir çalışma yapılmıştır [9]. Bu çalışmada meme kanseri tespitinde ve tedavi tekniklerinde, mikrodalganın gelişimi sayesinde kanserli ve normal meme dokularının dielektrik özelliklerinde önemli ölçüde bir fark olduğu sonucu elde edilmiştir. Bunun 
yanında, mikrodalga frekanslarında normal ve hastalıklı meme dokularının dielektrik özellikleriyle ilgili kesin bilgi daha önce yapılmış çalışmalara karşı uyumsuzluklarla ve haritalarla sınırlandırılmıştır. Bu çalışmada hassas ve sonu açık olarak sonlandırılmış bir koaksiyel prob kullanılmıştır. Normal, iyi huylu ve kanserli dokular üzerinde frekans aralığı 0,5 GHz'den 20 GHz'e kadar olacak şekilde ölçümler yapılmıştır. Böylece normal, iyi huylu ve kanserli dokuların dielektrik özelliklerini deneysel olarak belirleyebilmek için detaylı bir çalışma yapmışlar ve daha sonrada bir Cole-Cole modele yaklaştırarak karşılaştırmışlardır. Elde edilen sonuçlar yorumlanmıştır. Sonuç olarak, normal dokularla kanserli dokular arasında dielektriksel özellikler bakımından farklar olduğu ispatlanmıştır. Yapılmış olan bu çalışma dielektriksel özelliklerin farklarını göstermekle, deneysel çalışmaların önünü açmıştır. Ancak, dokunun ameliyattan çıkarılması ve ölçüm eş zamanlı gerçekleştirilmemiş ve ayrıca dokunun sadece kanserli ve iyi huylu olup olmadığ sınıflandırılmıştır. Ayrıca bu çalışmada mikrodalga dielektrik spektroskopi tekniği kullanılmıştır. Paslanmaz çelik ve borosilikat cam, hava geçirmeyecek şekilde kapatılmış kenardanbağımsız hassas problar, dielektrik sensörler olarak kullanılmıştır.

$3 \mathrm{~mm}$ yarıçapa sahip küçük prob, doku ile prob arasında mükemmel bir temas sağlamaktadır. Hava geçirmeyecek şekilde kapatılmış olması durumu da probun performansin uzun sürdürmesini sağlamıştır. Prob algılama derinliği 1-3mm'dir [10]. Bu durum çok küçük dokuların ölçümlerini garanti etmek açısından önemli olmuştur. Kalibrasyon düzleminde kompleks yansıma katsayıs1, bir vektör network analizör seti kullanılarak kaydedilmiş ve sonrasında da uygun bir metot [11] kullanılarak kompleks dielektrik sabitine dönüştürülmüştür. $\mathrm{Bu}$ tekniğin tutarlı performansını garanti etmek için, referans sıvılar kullanarak doğruluğunu onaylamışlardır. Doku üzerinden ölçümün iyi yapılabilmesi için prob seçiminin önemli olduğu görülmektedir [10].

Yapılan deneysel çalışmalarda dikkate alınması gereken en önemli noktalardan biri doku kullanımıdır. Ölçüme başlandığı zaman ile dokunun ameliyattan çıkarıldığı zaman arasındaki süre önemlidir [12]. Ayrıca her ölçümde dokunun sıcaklığı bir dijital termometre ile kaydedilmelidir. Şekil 1'de ameliyattan sonra çıkarılan kötü huylu dokunun ölçüme başlanmadan önceki hazırlığının fotoğrafi gösterilmiştir.

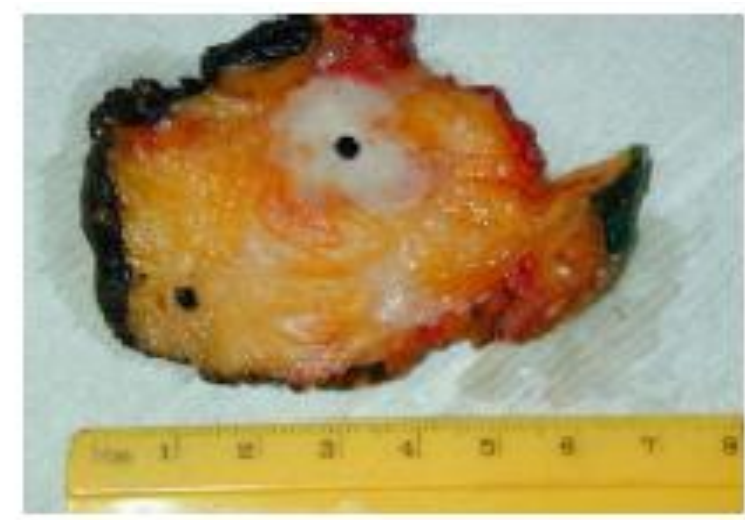

Şekil 1. Yağ (sarı renkli kısım) ve fibroglandular (beyaz renkli) dokusunun heterojen karışımını gösteren bir doku parçasının fotoğrafi. Ölçümün alınacağı kısımlar siyah mürekkep ile işaretlenir.

Mikrodalga ile meme kanseri tespiti için elektromanyetik saçılmanın sonlu eleman modellemesi çalışması yapılmıştır [13]. Mikrodalga tomografisi, dokular arası dielektriksel fark1 kullanan bir görüntüleme yöntemidir. Normal meme dokusu ile kötü doku (kanserli doku) arasındaki dielektriksel farkı göstererek meme kanseri tespiti için uygun bir seçenek sunmuşlardır.

Problemin geometrisi memenin koronal dilimlerini içerir [13]. Her dilim çeşitli katmanlardan oluşur. $\mathrm{Bu}$ katmanlar; deri (skin), yağ tabakası (adipose) ve fibroglandular'dır. Tümörün fibroglandular katmanının içinde bulunduğu düşünülür. 16 adet alıc1-verici anten dizisi memenin etrafinı dairesel olarak çevreler. Tüm bu geometri özel bir sıvıya batırılır. Şekil 2'de gösterildiği gibi yayılımı sadece bir anten yapar ve bu antene bitişik olmayan diğer antenler ise alan verisini elde ederler. 


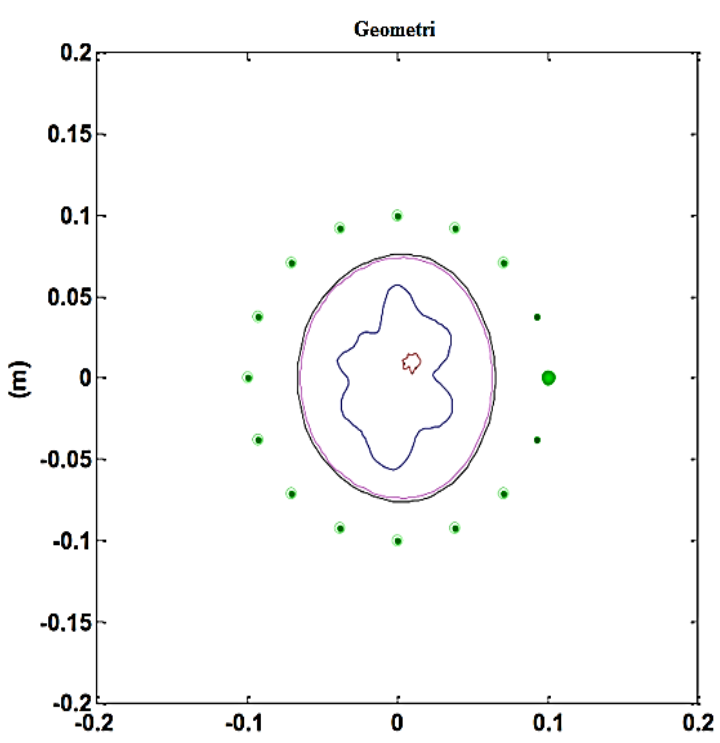

Şekil 2. En içten en dişa doğru katmanlar; tümör, fibroglandular, yağ tabakası (adipose) ve deri (skin). Bir anten, yayılımı yapan anten ve diğerleri de alıcılardır [13].

Elektromanyetik alan bileşenleri Maxwell'in denklemlerini sağlar ve her meme katmanındaki radyasyon şartı kompleks dielektrik özellikleri ile tanımlanır [13]. Meme tarafindan saçılan alanlar bu geometrinin fonksiyonlarıdır. $\mathrm{Bu}$ elektromanyetik alanları elde etmek için sonlu elemanlar ileri çözücüsü olarak COMSOL Multifizik kullanılmıştır.

Çoklu-frekans inversiyon probleminde, frekansa göre meme dokularının dielektrik özelliklerinin belirlenmesi gerekmektedir. $\mathrm{Bu}$ çalışmada, oluşturulan modele birinci dereceden veya ikinci dereceden Debye formülasyonu geniş bir şekilde uygulanmış [14] ve bu model ölçülen verinin denklem katsayılarına adapte edilmiştir. Birinci-dereceden Debye modeli aşağıdaki gibidir:

$\varepsilon_{r c}(\omega)=\varepsilon_{r}(\omega)+i \frac{\sigma(\omega)}{\omega \varepsilon_{0}}=\varepsilon_{\infty}+\frac{\varepsilon_{s}-\varepsilon_{\infty}}{1-i \omega \tau}+i \frac{\sigma_{s}}{\omega \varepsilon_{0}}$

$\varepsilon_{\mathrm{rc}}$ bağıl kompleks dielektrik sabiti, $\omega$ açısal frekans, $\varepsilon_{\mathrm{r}}$ bağıl dielektrik sabiti, $\sigma$ iletkenlik, $\varepsilon_{0}$ boş-uzay dielektrik sabiti, $\varepsilon_{\infty}$ sonsuz frekansta bağıl dielektrik sabiti, $\tau$ zaman sabiti (relaxation time constant) ve $\sigma_{\mathrm{s}}$ statik iletkenliktir. Burada, bağıl dielektrik ve iletkenlik aşağıdaki gibidir:

$\varepsilon_{r}(\omega)=\varepsilon_{\infty}+\frac{\varepsilon_{s}}{1+(\omega \tau)^{2}}$

$\sigma(\omega)=\omega^{2} \tau \varepsilon_{0} \frac{\varepsilon_{s}-\varepsilon_{\infty}}{1+(\omega \tau)^{2}}+\sigma_{s}$

Meme katmanlarının ve tümörün birinci-dereceden Debye formülasyonu için karakteristik parametreleri Çizelge 2'de gösterilmiştir.

Çizelge 2. Birinci-dereceden Debye parametreleri [13]

\begin{tabular}{|c|c|c|c|}
\hline Parametreler & $\boldsymbol{\varepsilon}_{\infty}$ & $\boldsymbol{\varepsilon}_{\boldsymbol{s}}$ & $\boldsymbol{\sigma}_{\boldsymbol{s}}$ \\
\hline Deri (Skin) & 15,3 & 40,1 & 0,4 \\
\hline $\begin{array}{c}\text { Yağ Tabakası } \\
\text { (Adipose) }\end{array}$ & 3,18 & 5,02 & 0,043 \\
\hline Fibroglandular & 16,8 & 36,7 & 0,461 \\
\hline Tümör (Tumor) & 18,8 & 46,8 & 0,803 \\
\hline
\end{tabular}

Şekil 2'de gösterilen meme katmanlarının geometrisi MATLAB'da uygulanmış ve COMSOL Multifizik programına aktarılmıştır. Bağıl dielektrik ve iletkenlik fonksiyonları (2) ve (3) nolu eşitliklerde olduğu gibi COMSOL'da analitik olarak tanımlanmışlardır. Sonuç olarak; MATLAB'da yazılan FDFD kodunun sonuçları ile COMSOL'da üretilen sonuçlar karşılaştırılmıştır ve nümerik sonuçlar elde edilmiştir.

Meme kanseri tedavisi için örnek bir meme oluşturarak bunun dielektrik özelliklerinin ölçümüyle ilgili bir çalışma yapılmıştır [15]. Birçok örnek modeller tümörün ve normal dokunun belirgin tanımlarını içermezler. $\mathrm{Bu}$ çalışma meme kanseri tedavisinde hipertermi için Şekil 3'de gösterilen somut bir meme-tümör örneği önermiştir. Bu somut meme ve tümör örneklerinin nasıl yapıldığıyla ilgili ayrıntılı bilgi ilgili çalışmada anlatılmıştır [15]. Ölçümler dielektrik spektroskopi metodu kullanılarak elde edilmiştir [10]. Dielektrik sabiti ve elektriksel iletkenlik ölçümleri, E5071B ENA Series Network Analyzer ve 85070 Dielectric Probe Kit kullanılarak gerçekleştirilmiştir. Dielectric Kit 
probları kalibrasyon için network analizörüne bağlanmıştır. Analizörün kalibrasyonundan sonra ölçümlere başlanmıştır. Bir network analizör ve bir dielektrik prob kit kullanarak hem normal hem de kanserli doku üzerinde ölçümler yapılmıştır. Literatürle karşılaştırıldığında sonuçlar oldukça uyumlu çıkmıștır. Örnek bir meme oluşturmak hipertermi uygulamaları için bir avantaj olurken veri çeşitliliği bakımından avantaj olmamaktadır.

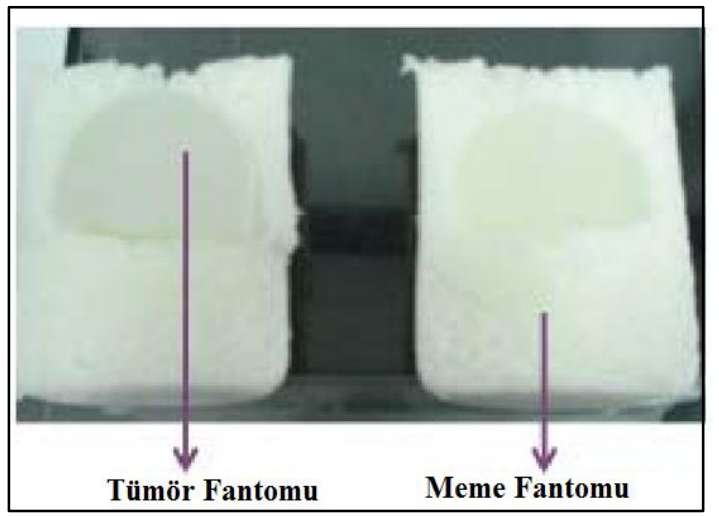

Şekil 3. Meme-tümör örneği (Breast-tumor phantom) [15].

Meme tümörlerinin mikrodalga görüntüleme uygulamasının şekil tabanlı bir inversiyon algoritması oluşturulmuştur [16]. Simülasyon ortamında oluşturulan meme modeli Şekil 4'de gösterilmiştir. Yapılmış olan bu çalışma sonlu eleman modellemesine [13] benzer bir çalışmadır. Fakat bu çalışmada geometrilerini homojen olmayan bir katmana koymuşlardır. İnversiyon algoritması da uygun geometrilerin düşük-boyutlu parametrik formuna dayanmaktadır.

Mikrodalga ile meme kanseri tespitinin deneysel durumları için doku örnekleri geliştirilmiştir [12]. $\mathrm{Bu}$ durumun bu kadar üstünde durulmasının sebebi hiperterminin deneysel çalışmalarına en azından daha gerçekçi bir örnek sağlamaktır.

$\mathrm{Bu}$ çalışmada da mikrodalga ile meme kanseri tespitinde gerçekçi meme örneklerinin yapımıyla ilgili bir yöntem sunulmaktadır [12]. Yağ tabakası, deri, bez ve tümör örnekleri günlük yaşamda kullanılan kimyasal maddelerin karışımlarından oluşmaktadır. Cizelge $3 a$ ve Çizelge $3 b$ 'de kullanılan maddeler ile miktarları verilmiştir. Oluşturulma işlemleri tamamlandıktan sonra bu örneklerin dielektrik geçirgenlikleri ve iletkenlikleri mikrodalga frekanslarında ölçülmüştür. Son olarak, tek meme örneği içine bu oluşturulan örnekleri yerleştirmek için bir metot tanımlamışlardır.

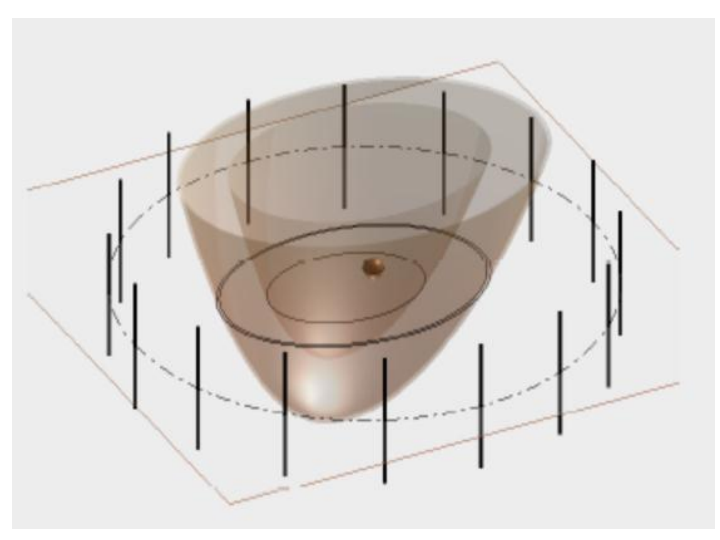

Şekil 4. En içteki katmana yerleştirilmiș tümör ile beraber meme katmanlarının 3-boyutlu geometrisi [16].

Çizelge 3a. Her doku örneği için kullanılan maddeler ve miktar listesi [12]

\begin{tabular}{|l|c|c|}
\hline $\begin{array}{c}\text { Üretilecek kısımlar } \\
\text { ve üretimde } \\
\text { kullanılacak } \\
\text { maddelerin } \\
\text { miktarları }\end{array}$ & $\begin{array}{c}\text { Yağ } \\
\text { Tabakası } \\
\text { (Fat) }\end{array}$ & $\begin{array}{c}\text { Beze } \\
\text { Tabakası } \\
\text { (Gland) }\end{array}$ \\
\hline p-toluic acid (g) & 0,13 & 0,25 \\
\hline n-propanol (mL) & 6,96 & 12,1 \\
\hline deionized water (mL) & 132,70 & 241,9 \\
\hline 200 Bloom gelatin (g) & 24,32 & 43,27 \\
\hline Formaldehyde (g) & 1,53 & 2,74 \\
\hline Oil (mL) & 265,6 & 141,5 \\
\hline $\begin{array}{l}\text { Ultra Ivory detergent } \\
\text { (mL) }\end{array}$ & 12,00 & 6,79 \\
\hline
\end{tabular}


Çizelge 3b. Her doku örneği için kullanılan maddeler ve miktar listesi [12]

\begin{tabular}{|c|c|c|}
\hline $\begin{array}{c}\text { Üretilecek kısımlar } \\
\text { ve üretimde } \\
\text { kullanılacak } \\
\text { maddelerin } \\
\text { miktarları }\end{array}$ & $\begin{array}{c}\text { Deri } \\
\text { (Skin) }\end{array}$ & $\begin{array}{c}\text { Tümör } \\
\text { (Tumour) }\end{array}$ \\
\hline p-toluic acid (g) & 0,294 & 0,346 \\
\hline n-propanol (mL) & 28,69 & 17,00 \\
\hline $\begin{array}{c}\text { deionized water } \\
\text { (mL) }\end{array}$ & 27,50 & 328,0 \\
\hline $\begin{array}{c}\text { 200 Bloom gelatin } \\
\text { (g) }\end{array}$ & 50,02 & 58,67 \\
\hline Formaldehyde (g) & 3,33 & 3,72 \\
\hline Oil (mL) & 98,60 & 38,40 \\
\hline $\begin{array}{c}\text { Ultra Ivory } \\
\text { detergent (mL) }\end{array}$ & 5,86 & 2,00 \\
\hline
\end{tabular}

$\mathrm{Bu}$ çalışmadaki önemli noktalardan biri deneyin yapılma zamanıdır. Deney yapıldığında oluşturulan örnek dokunun taze olup olmaması bağıl geçirgenlik değerlerini etkilemiştir. Şekil 5'de yağ tabakası örneğinin frekansa karşı bağıl geçirgenlik grafiği gösterilmiştir. Mavi renkli çizgi yağ doku örneğinin taze durumunu, kırmızı renkli olan ise 6 ay bekletildiği durumunun frekansa karşı hareketini göstermektedir. Grafikten de görüldüğü üzere 6 ay bekletilen durumda bağıl geçirgenlik azalmaktadır.

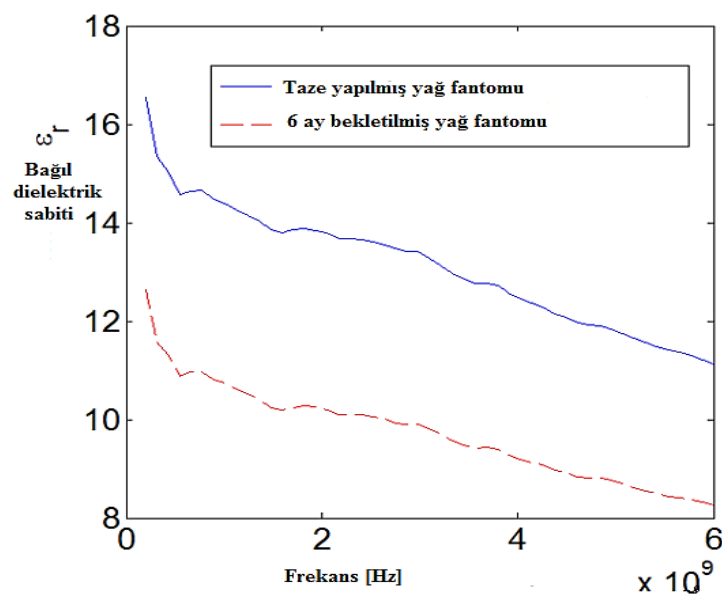

Şekil 5. Frekansa karşı bağıl geçirgenlik grafiği [12]
Tümörün erken tespiti için mikrodalga ile meme görüntülemenin bir metodu olarak "Doku algilamaya uygun radar (Tissue Sensing Adaptive Radar: TSAR)" önerilmiştir [17]. Bu radar, ilgilenilen hacim içindeki tüm dokuları bulur ve ona göre adapte eder. Simülasyon sonuçları, $4 \mathrm{~mm}$ yarıçaplı olan tümörlerin tespiti için bu sistemin uygulanabilirliğini göstermiştir. Yapılan simülasyon çalışmalarının sonuçları ile deney sonuçları karşılaştırılmıştır. Şekil 6'da bu çalışmada kurulan deney düzeneği gösterilmiştir.

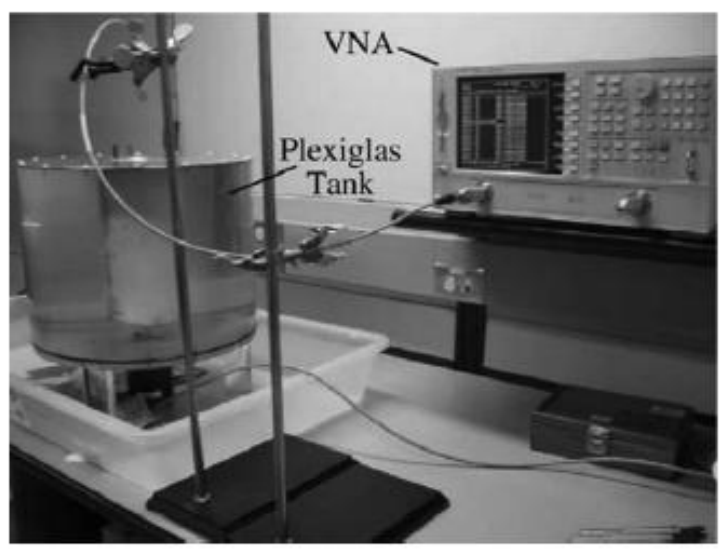

Şekil 6. Deney seti [17]

Normal meme dokusu ile kanserli doku arasındaki ayrımı kullanarak bir koaksiyel prob ölçüm sistemiyle test yapılmıştır [18]. Aynı zamanda Şekil 7'de de gösterildiği gibi çalışmalarını bir simülasyon ortamında da gerçekleştirmişlerdir. Simülasyon çalışmalarını HFSS olarak adlandırılan bir simülasyon programında yapmışlardır. Deneyde bir "Agilent E8363B PNA Vector Network Analyzer" ve bir “Agilent 85070D Dielectric Probe" kullanmışlardır. Şekil 8'de ölçüm sisteminin blok şeması gösterilmiştir.

Bunlara ek olarak, test altındaki dokunun kanserli olup olmadığıyla ilgili son kararı verebilmek için "sinir ağı (neural network)" tekniğini önermişler ve uygulamışlardır.

İyi huylu ve kötü huylu meme dokusunun dielektrik özellikleriyle ilgili daha önce geniş çapta 


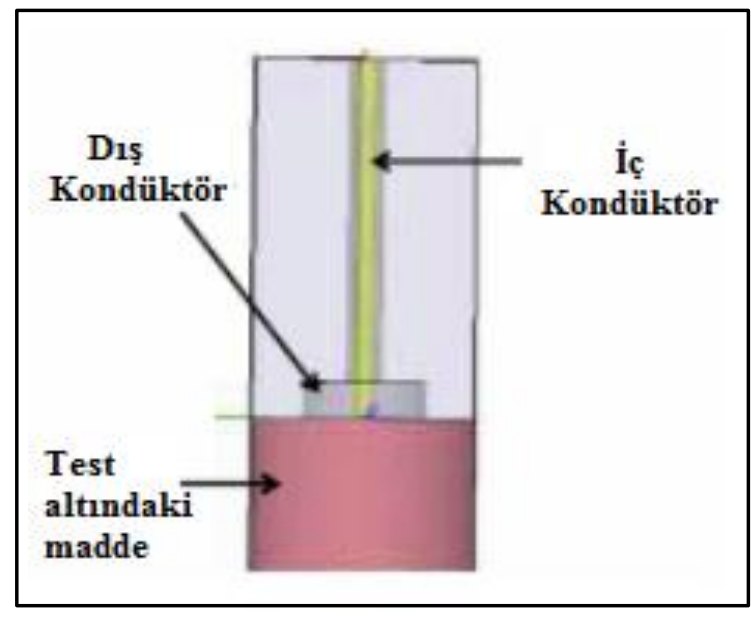

Şekil 7. Test altındaki dokuyla beraber koaksiyel probun HFSS modeli

yapılmış deneysel çalışmayı $0,5 \mathrm{GHz}$ ile $20 \mathrm{GHz}$ arasında geçerli olan Cole-Cole modellerine uygulamışlardır [19]. Cole-Cole modellerini referans alarak, $0,5 \mathrm{GHz}$ ile $20 \mathrm{GHz}$ arasında meme dokusunun dielektrik özelliklerinin birkutuplu ve iki-kutuplu Debye modellerinin parametrelerini türetmişlerdir.
Ayrıca, bir kutuplu Debye modellerini Cole-Cole datasına yaklaştırmışlardır. Her iki-kutuplu Debye modelinin yine $0,5 \mathrm{GHz}$ ile $20 \mathrm{Ghz}$ arasinda Cole-Cole modeline uygunlukta mükemmel olduğunu ispatlamışlardır. Diğer yandan tek-kutuplu Debye modeli bunu sağlamamıştır. Ancak frekans aralı̆g $13,1 \mathrm{GHz}$ ile $10,6 \mathrm{GHz}$ olduğunda uygunluğun yine mükemmel olacağını önermişlerdir.

Sağlıklı ve kanserli meme dokularının mikrodalga frekanslarında dielektrik özellikleri arasında önemli fark bulunmaktadır [20]. Mikrodalga meme kanseri tespitinin klinik etkinliğinin ve hipertermi tedavi tekniklerinin iyi ve kötü huylu meme dokularının dielektrik özellikleriyle ilişkili olacağı literatürdeki diğer çalışmalarda da vurgulanmıştır $[21,22]$.

Mikrodalga görüntüleme, en güncel meme kanseri tespit ve görüntüleme tekniklerinden biridir [23-28] ve güvenli ve verimli bir meme kanseri tarama metodu olarak büyük bir potansiyele sahiptir. Literatürde yer alan ve bu konuda yapılan çalışmalar, mikrodalga ile görüntülemenin, meme kanseri tespiti için diğe $r$ yöntemlere göre daha

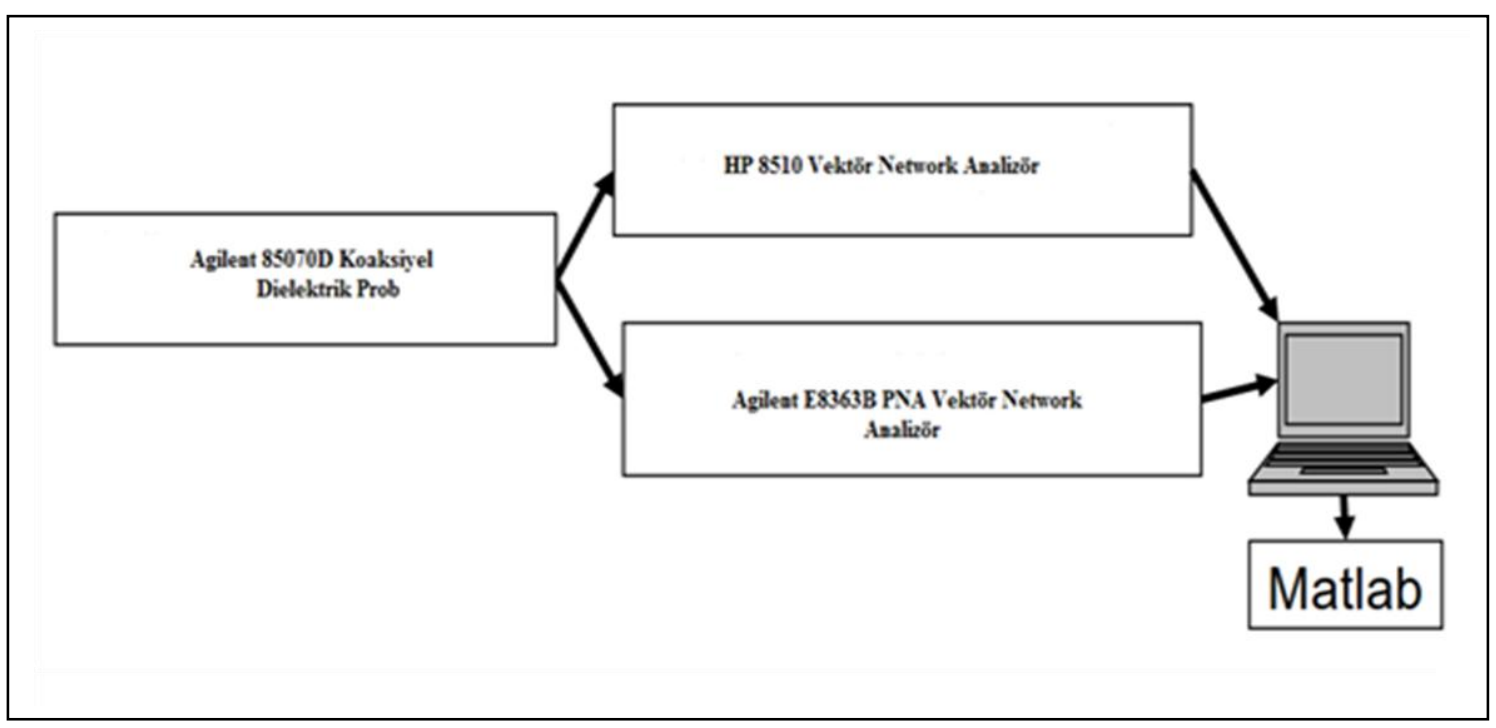

Şekil 8. Koaksiyel prob ölçüm sisteminin blok şeması [18] 
ucuz, güvenli bir teknik olduğunu göstermektedir ve çalışmalar devam etmektedir.

\section{Kanserli-Sağlıklı Meme Dokularının Yapay Zeka Algoritmaları ile Tanımlanabilmesi}

Literatürdeki veri seti, İleri Beslemeli Geriye Yayılımlı Yapay Sinir Ağı (İBGY-YSA) ve Destek Vektör Makineleri (DVM) gibi yapay zekâ algoritmalarının eğitilmeleri için kullanarak, hangi algoritmanın daha iyi sonuç verdiği bulunacaktır. Bunun amac1; normal doku olarak bilinen, bağ dokusu (connective tissue), yağ dokusu (adipose tissue), glandüler doku (glandular tissue) ile patalojik doku olarak bilinen, kanserli hücre dokusu (carcinoma), fibroadenom doku (fibroadenoma), mastopati (matopathy) arasındaki farklılıkları ortaya koyabilecek şekilde eğitildikten sonra hangi gruba dahil olduğu bilinmeyen, dielektrik özellikleri ölçülmüş ve hastanın karakteristik özellikleri belirlenmiş dokuyu bu iki sınıftan birine (patolojik ya da normal) en doğru şekilde atamaktır.

Dokuların elektriksel özelliklerini kullanarak sınıflandırılabileceklerini göstermek açısından şöyle bir çalışma gerçekleştirilmiştir. Daha önce Jossinet J. tarafindan 1996 yılında yayınlanan "Variability of impedivity in normal and pathological breast tissue" isimli çalışması için oluşturulan ve 2010 yılından itibaren serbest kullanım için paylaşılan veri setinde [29], $488 \mathrm{~Hz}$ ile $1 \mathrm{MHz}$ arasındaki değişik frekans değerlerinde, sağlıklı ve kanserli doku hücrelerinin elektriksel empedans1 spektroskopi (EES) yöntemi ile ölçümleri yapılmıştır. Bu veri setinin oluşturulması sırasında, 106 hastadan alınan doku örnekleri üzerinde yapılan ölçümler sonrasında Şekil 9'da gösterilen EES grafikleri elde edilmiş ve bu grafikler kullanılarak 9 tane özellik ile bu özelliklerin ait olduğu doku grupları, carcinoma, fibro-adenoma, mastopathy, glandular, connective, adipose kullanılmıştır.

Ölçüm yapılan frekans değerleri Çizelge 4'te ve belirlenen özellikler Çizelge 5'te verilmiştir.

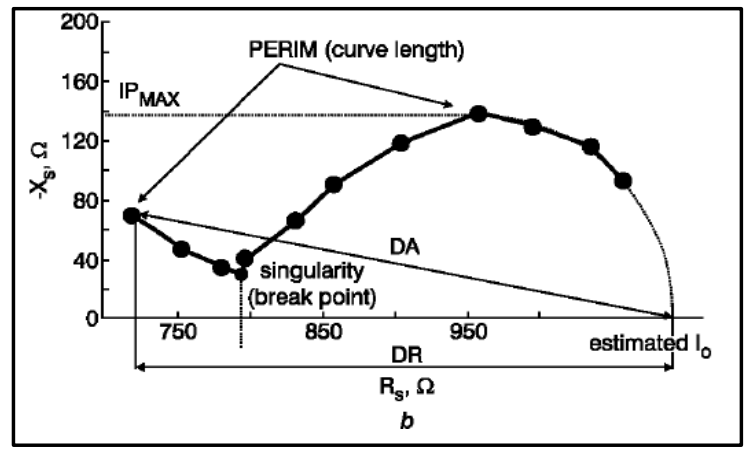

Şekil 9. Özelliklerin çıkarıldığı, örnek EES grafiği

Çizelge 4. EES ölçümleri yapılırken kullanılan frekans değerleri

\begin{tabular}{|c|}
\hline Frekans Değerleri (KHz) \\
\hline 15,625 \\
\hline 31,250 \\
\hline 62,500 \\
\hline 125 \\
\hline 250 \\
\hline 500 \\
\hline 1000 \\
\hline
\end{tabular}

Çizelge 5. EES grafiklerinden elde edilen özellikler

\begin{tabular}{|l|l|}
\hline \multicolumn{1}{|c|}{ Özellik } & \multicolumn{1}{|c|}{ Tanımı } \\
\hline I0 & Sıfır frekansında empedans değeri \\
\hline PA500 & \begin{tabular}{l} 
500 Khz frekansta faz açısı \\
\hline HFS \\
eğimi
\end{tabular} \\
\hline DA & $\begin{array}{l}\text { Spektral uçlar arasındaki empedans } \\
\text { mesafesi }\end{array}$ \\
\hline AREA & Grafiğin altında kalan alan \\
\hline A/DA & DA ile normalize edilmiş alan \\
\hline MAX IP & Grafiğin maksimum değeri \\
\hline DR & $\begin{array}{l}\text { I0 ile maksimum frekans } \\
\text { noktasının reel kısmı arasındaki } \\
\text { mesafe }\end{array}$ \\
\hline P & \begin{tabular}{l} 
Spektral eğrinin uzunluğu \\
\hline
\end{tabular} \\
\hline
\end{tabular}


Yapılan bu çalışmada amaç, sözü edilen veri setini kullanarak DVM ve İBGY-YSA algoritmaları ile bir sinıflandırma modeli oluşturmaktır. Bu nedenle, öncelikle 106 örnekten oluşan veri seti içinden bir örnek çıkarılmış ve geri kalan örnekler 21 elemanlı 5 eşit parçaya bölünmüştür. Çapraz doğrulama metodu kullanılarak, her seferinde yapay sinir ağ 4 örnek grubu ile eğitilmiş geriye kalan 1 grup ile test edilmiştir. Başarı ölçütü olarak duyarlılık (sensitivity) (5) diğer bir değişle kullanılan test ile sonucu pozitif çıkan bir hastanın kanserli olma ihtimali ve özgüllük (specificity) (6) aynı test ile sonucu negatif çıkan bir hastanın sağlıklı olma ihtimali değerleri hesaplanmıştır. Duyarlılık ve özgüllük değerleri hesaplanırken, Doğru Pozitif, kanserli hastalardan doğru bir şekilde kanserli olarak sınıflandırılanların sayısını, Yanlıș Pozitif, sağlıklı olmasına rağmen kanserli olarak sınıflandırılan hastaların sayısını, Doğru Negatif, sağlıklı hastalardan doğru bir şekilde sağlıklı olarak sınıflandırılanların sayısını, Yanlış Negatif, hasta olmasına rağmen sağlıklı olarak sınıflandırılan hastaların sayısını temsil etmektedir. Her iki algoritma için elde edilen değerler, her bir veri grubu için Çizelge 6'da verilmiştir.

$$
\begin{aligned}
& \text { Duyarlılık }=\frac{\text { Doğru Pozitif }}{\text { Doğru Pozitif }+ \text { Yanlış Negatif }} \\
& \text { Özgüllük }=\frac{\text { Doğru Negatif }}{\text { Doğru Negatif+Yanlış Pozitif }}
\end{aligned}
$$

Çizelge 6'da verilen özgüllük değeri, sistemin hasta olmayan kişileri doğru belirleme oranı, duyarlılık ise hasta olanların, hasta olarak teşhis edilme oranı olarak tanımlanabilir. Elde edilen sonuçlara bakarak İBGY-YSA algoritmasının, duyarlılık açısından daha iyi sonuç verdiği, DVM algoritmasının ise özgüllük açısından daha iyi olduğu görülmektedir. Çalışmadaki sonuçlara göre, elektriksel özellikleri göz önüne alındığında, kanserli ve normal meme dokularının bu metotlarla tanımlanabildikleri görülmektedir.

\section{SONUÇ}

Mikrodalga ile görüntüleme, mikrodalga frekanslarında doku dielektrik özelliklerindeki yüksek oranda zıtlık nedeniyle meme kanseri tespiti için önemli bir potansiyele sahiptir.

Çizelge 6. İBGY-YSA ve DVM algoritmaları kullanılarak elde edilen duyarlılık ve özgüllük değerleri

\begin{tabular}{|c|c|c|c|c|}
\hline & \multicolumn{2}{|c|}{ Duyarlılı } & \multicolumn{2}{c|}{ Özgüllük } \\
\hline $\begin{array}{c}\text { Veri } \\
\text { Grubu }\end{array}$ & FFBP-NN & SVM & $\begin{array}{c}\text { FFBP- } \\
\text { NN }\end{array}$ & SVM \\
\hline $\mathbf{1}$ & 0,7778 & 0,7273 & 0,9167 & 1,0000 \\
\hline $\mathbf{2}$ & 0,7059 & 0,6667 & 1,0000 & 1,0000 \\
\hline $\mathbf{3}$ & 0,8889 & 0,8571 & 0,6667 & 1,0000 \\
\hline $\mathbf{4}$ & 0,8667 & 0,8125 & 1,0000 & 1,0000 \\
\hline $\mathbf{5}$ & 0,6923 & 0,6000 & 1,0000 & 1,0000 \\
\hline
\end{tabular}

Mikrodalga ile yapılan her yöntemin zayıf ve güçlü yanları vardır, ama her türlü yaklaşımı keşfederek araştırma ve gelişme miktarı büyümeye devam etmektedir. Diğer yandan, dokuların elektriksel özelliklerini kullanarak sınıflandırılabileceklerini göstermek açısından literatürdeki veri seti kullanılarak İleri Beslemeli Geriye Yayılımlı Yapay Sinir A ğı (İBGY-YSA) ve Destek Vektör Makineleri (DVM) algoritmaları ile bir sinıflandırma modeli oluşturulmuştur. IBGY-YSA algoritması duyarlılık açısından daha iyi sonuç verirken DVM ise özgüllük açısından daha iyi sonuç vermiştir. Sonuç olarak, elektriksel özellikler göz önüne alındığında, kanserli ve sağlıklı meme dokularının, bu yöntemlerle tanımlanabildikleri görülmektedir.

\section{TEŞEKKÜR}

Değerli bilgilerini, önerilerini ve yardımlarını esirgemeyen Danışmanım Sayın Prof. Dr. A. Hamit SERBEST’e teşekkür ederim.

\section{KAYNAKLAR}

1. Biçer, M. B., Avşar Aydın, E., Akdağlı, A., 2014. Meme Kanseri Görüntülenmesinde 
Mikrodalganın Yeri, Erciyes Üniversitesi Fen Bilimleri Enstitü Dergisi.

2. Meme Kanseri, Wikipedia, http://tr.wikipedia.org/wiki/Meme_kanseri, [Erişim: Şubat 2014].

3. Fear, E.C.X., Hagness S.C., Stuchly M. A., 2002. Confocal Microwave Imaging for Breast Cancer Detection: Localization of Tumors in Three Dimensions, IEEE Transactions on Biomedical Engineering, 49, 812-822.

4. Hagness, S. C., Taflove, A., Bridges J. E., 1998. Two-Dimensional FDTD Analysis of a Pulsed Microwave Confocal System for Breast Cancer Detection: Fixed-Focus and Antenna-Array Sensors, IEEE Transactions on Biomedical Engineering, 45, 1470-1479.

5. Karpat, E., 2009. Gömülü ve/veya Örtülü Nesnelerin Algilanmasinda Yeni Yaklaşımlar, Doktora Tezi, Uludağ Üniversitesi, Fen Bilimleri Enstitüsü.

6. Fear, E., Stuchly, M., 2003. Microwaves for Breast Cancer Detection?, IEEE Potentials

7. Paulsen, K., Meaney, P., Gilman, L., 2005. Alternative Breast Imaging Four ModelBased Approaches, Springer, ABD.

8. Meme Kanseri Önlenebilir mi?, http://www.memeonline.net/icerik/45/memekanseri-onlenebilir-mi-.aspx, [Erişim: 25 Temmuz 2014].

9. Lazebnik, M., McCartney, L., Popovic, D., Watkins, C.,Lindstrom, M., Harter, J., Sewall, S., Magliocco, A., Booske, J., Okoniewski, M., Hagness, S., 2007. A LargeScale Study of the Ultrawideband Microwave Dielectric Properties of Normal, Benign and Malignant Breast Tissues Obtained Cancer Surgeries, IOP Publishing, Phys. Med. Biol., Cilt 52, 6093-611.

10. Hagl, D. M., Popovic, D., Hagness, S., Booske, J., Okoniewski, M., 2003. Sensing Volume of Open-Ended Coaxial Probes for Dielectric Characterization of Breast Tissue at Microwave Frequencies, IEEE Trans. Microw. Theory Tech., Cilt 51, 1194-206.

11. Popovic, D., McCartney, L., Beasley, C., Lazebnik, M., Okoniewski, M., Hagness, S., Booske, J., 2005. Precision Open-Ended Coaxial Probes for in Vivo and Ex Vivo
Dielectric Spectroscopy of Biological Tissues at Microwave Frequencies, IEEE Trans. Microw. Theory Tech., Cilt 53, No. 5, 171322.

12. Porter, E., Fakhoury, J., Oprisor, R., Coates, M., Popovic, M., 2010. Improved Tissue Phantoms for Experimental Validation of Microwave Breast Cancer Detection, Antennas and Propagation (EuCAP), 2010 Proceedings of the Fourth European Conference on, Barcelona, Spain, 12-16 April

13. Firoozabadi, R., Miller, E., 2010. Finite Element Modeling of Electromagnetic Scattering for Microwave Breast Cancer Detection, Excerpt from the Proceedings of the COMSOL Conference, Boston.

14. Gandhi, O., Gao, B.,Chen, J., 1993. A-Frequency Dependent Finite-Difference Time-Domain Formulation for General Dispersive Media, IEEE Transactions on Microwave Theory and Techniques, 41.

15. Ortega-Palacios, R., Leija, L., Vera, A., Cepeda, M. F.J., 2010. Measurement of Breast-Tumor Phantom Dielectric Properties for Microwave Breast Cancer Treatment Evaluation, $20107^{\text {th }}$ International Conference on Electrical Engineering, Computing Science and Automatic Control (CCE 2010) Tuxtla Gutiérrez, Chiapas, México.

16. Firozabadi, R., Miller, E., 2011. A Shape-Based Inversion Algorithm Applied to Microwave Imaging of Breast Tumors, IEEE Transactions on Antennas and Propagation, 59 ,

17. Sill, J., Fear, E., 2005. Tissue Sensing Adaptive Radar for Breast Cancer DetectionExperimenal Inverstigation of Simple Tumor Models, IEEE Trans. Microw. Theory Tech., 53.

18. Kuhn M., 2010. Open-Ended Coaxial Probe Measurements for Breast Cancer Detection, RWS'10 Proceedings of the 2010 IEEE conference on Radio and Wireless Symposium, 512-515.

19. Lazebnik, M., Okoniewski, M., Booske, J., Hagness, S., 2007. Highly Accurate Debye Models for Normal and Malignant Breast Tissue Dielectric Properties at Microwave Frequencies, 17, No. 12. 
20. Lazebnik, M., Booske, J., Popovic, D., McCartney, L., Okoniewski, M., Lindstrom, M., Breslin, T., Harter, J., Sewall, S., Temple, W., Mew, D., Magliocco, A., Ogilvie, T., 2007. The Dielectric Properties of Normal and Malignant Breast Tissue at Microwave Frequencies: Analysis, Conclusions, and Implications from the Wisconsin/Calgary Study, IOP Publishing Phys. Med. Biol., 52, 6093-6115.

21. Li, X., Bond, E., VanVeen, B., Hagness, S. 2005. An Overview of Ultrawideband Microwave Imaging via Space-Time Beamforming for Early-Stage Breast Cancer Detection, IEEE Antennas and Propagation Magazine, 47, No. 1.

22. Converse, M., Bond, E., Hagness, S., Van Veen, B., 2004. Ultrawideband Microwave Space-Time Beamforming for Hyperthermi Treatment of Breast Cancer: A Computational Feasibility Study, IEEE Trans. Micr. Theory Tech., 52:1876-89.

23. Kirshin, E., Oreshkin, B., Zhu, G. K., Popovic, M., Coates, M., 2013. Microwave Radar and Microwave-Induced Thermoacoustics: Dual-Modality Approach for Breast Cancer Detection, IEEE Transactions on Biomedical Engineering, 60, 354-360.

24. Shahzad, A., O'Halloran, M., Jones, E., Glavin, M., 2013. Prefiltered Beamforming for Early-Stage Breast Cancer Detection, IEEE Antennas and Wireless Propagation Letters, 12, 500-503.

25. Kwon, S. ve Lee, S., 2013 Instantaneous Microwave Imaging with Time-Domain Measurements for Breast Cancer Detection, IEEE Electronics Letters, 49.

26. Ghavami, N., Tiberi, G., Edwards, D.J., Monorchio, A., 2012. UWB Microwave Imaging of Objects with Canonical Shape, IEEE Transactions on Antennas and Propagation, 60, 231-239.

27. Bassi, M., Caruso, M., Khan, M.S., Bevilacqua, A., Capobianco, A. D., Neviani, A., 2013. An Integrated Microwave Imaging Radar with Planar Antennas for Breast Cancer Detection, IEEE Transactions on
Microwave Theory and Techniques, 61, 2108-2118.

28. Fouda, A. E., Teixeira, F. L., 2014. UltraWideband Microwave Imaging of Breast Cancer Tumors via Bayesian Inverse Scattering, Journal of Applied Physics, 115.

29. Frank, A., Asuncion, A., 2010. UCI Machine Learning Repository [http://archive.ics.uci.edu/ml], Breast Tissue Dataset. Irvine, CA: University of California, School of Information and Computer Science, [Erişim: 28 Kasım 2013]. 